\title{
Studies on curative treatment of red palm weevil, Rhynchophorus ferrugineus Olivier infested date palms based on an innovative fumigation technique
}

\author{
S.R. Al Ballaa ${ }^{1}$ and J.R. Faleiro ${ }^{2}$ \\ (1) Infectious Diseases and Medical Microbiology, King Saud University, Kingdom of Saudi Arabia, \\ email: sballaa@ gmail.com; (2) Food and Agriculture Organization of the UN, Goa, India.
}

\begin{abstract}
Al Ballaa S.R. and J.R. Faleiro. 2019. Studies on curative treatment of red palm weevil, Rhynchophorus ferrugineus Olivier infested date palms based on an innovative fumigation technique. Arab Journal of Plant Protection, 37(2): 119123.

The Red Palm Weevil (RPW) Rhynchophorus ferrugineus Olivier (Coleoptera: Curculionidae) is a key pest of date palm Phoenix dactylifera L. in the Near East and North Africa region. RPW infested date palms respond to curative chemical treatments if detected and judiciously treated in the early stage of attack. However, the currently used curative treatments, involve either excessive tissue removal of the palm around the infested palm section (mechanical sanitization) making the palm weak and vulnerable to toppling, injecting insecticide into the infested palms which often does not kill all the stages of the pest within the palm, calling for repeated applications or fumigating the infested palm section with phosphine gas which is also not always effective, possibly due to inadequate dose and escape of the gas. A new fumigation technique involving treatment of infested date palms with aluminium phosphide tablets $(3 \mathrm{~g})$ ensuring complete entrapment of phosphine gas was devised and field tested in 295 RPW infested date palms in various stages of attack in Al-Qassim, Kingdom of Saudi Arabia, during 20172018. The technique was tested in both young date palms (9-12 years old) as well in offshoots (4 years old), through a series of field trials to optimize the number of applications, dose, duration of treatment and type of wrapping to entrap the gas. Results revealed that for young date palms in the susceptible age of attack to RPW, a single application of 10 aluminium phosphide tablets for 5 days inserted in air tight black plastic wrapping resulted in complete mortality of larva, pupae and adult stages of the pest. Further, in offshoots, a single treatment with 15 aluminium phosphide tablets inserted in air tight transparent plastic wrapping for 10 days ensured complete mortality of the pest within the palm. The technique can be used for both field treatment of infested palms as well for quarantine treatment of date palm offshoots and is gaining popularity in Saudi Arabia.

Keywords: Saudi Arabia, offshoots, aluminium phosphide, quarantine, curative treatment.
\end{abstract}

\section{Introduction}

The Red Palm Weevil (RPW) Rhynchophorus ferrugineus Olivier (Coleoptera: Curculionidae) is a key pest of date palm Phoenix dactylifera L. (Faleiro, 2006). RPW is native to South and South-East Asia where it is a major pest of coconut Cocos nucifera. After gaining foot hold on date palm in the mid-1980s the pest spread to the Middle-East, North Africa and the Mediterranean basin countries mainly through infested planting material transported for agricultural and ornamental gardening, calling for strict pre- and post-entry quarantine regimes.

The pest is reported to attack 40 palm species in diverse agro-ecosystems worldwide (Giblin-Davis et al., 2013) and likely to expand its geographical range (Fiaboe et al., 2012). Most recent introductions of RPW are from Abkhazia in the Republic of Georgia and in Djibouti in East Africa (Faleiro et al., 2018). Palm weevils threaten agricultural (date plantations) and natural areas (palm oases) (Milosavljević, 2018).

RPW is an internal tissue borer that is difficult to detect. Palms in the late stage of attack exhibit extensive tissue damage due to larval feeding. Such palms harbour several overlapping generations of RPW and are beyond any curative treatment. These palms have to be eradicated. RPW infested date palms respond to curative chemical treatments if detected and judiciously treated in the early stage of attack (Abraham et al., 1998). However, the currently used curative treatments, involve either excessive tissue removal of the palm around the infested palm section (mechanical sanitization) often making the palm weak and vulnerable to toppling, injecting insecticide into the infested palms which always does not kill all the stages of the pest within the palm, calling for repeated applications or fumigating the infested palm section with phosphine gas which is also not always effective due to inadequate dose and escape of the gas.

Insecticide applications are, at present, the most effective method for protecting palms from attack by palm weevils (Milosavljević, 2018). Although, curative treatments of RPW infested date palms using aluminium phosphide is widely practiced in UAE and the state of Bahrain, there is no information on the dose and duration of treatment using aluminium phosphide to safely and effectively treat RPW infested date palms.

In this study, treatment of RPW infested date palms with aluminium phosphide tablets was extensively evaluated in the Kingdom of Saudi Arabia with an objective to standardise the dose and duration of treatment for its safe and effective use. The protocols adopted and results obtained are presented below. 


\section{Materials and Methods}

During the end of 2017 and early 2018, a series of field experiments were conducted by Rasheed Mohammed Al Ballaa and Munira Mohammed Al-Hothaili Endowment fund (May the Mercy of Allah be upon them) in Al-Qassim region of Saudi Arabia, with an aim to develop an effective, low-cost and easy to apply curative treatment method to control the RPW in infested palm trees using aluminium phosphide. The trials were based on the hypothesis that RPW needs oxygen to survive, air reaches RPW stages within the palm tree through the feeding tunnels cavities, the tunnels are connected to outside air and can be used to deliver fumigants. Keeping this in view a new fumigation protocol involving treatment of infested date palms with aluminium phosphide tablets (3 g, 50-60\% a.i.) ensuring complete entrapment of phosphine gas was devised and field tested in over 400 infested palms including 295 RPW infested date palms in various stages of attack reported under this study. Material and apparatus used to assemble a gas entrapment chamber on the infested palm is depicted in figure 1 . The technique was tested in both young date palms (9-12 years old) as well in offshoots (4 years old), through a series of field trials to optimize the number of applications, dose, duration of treatment and type of wrapping to entrap the gas.

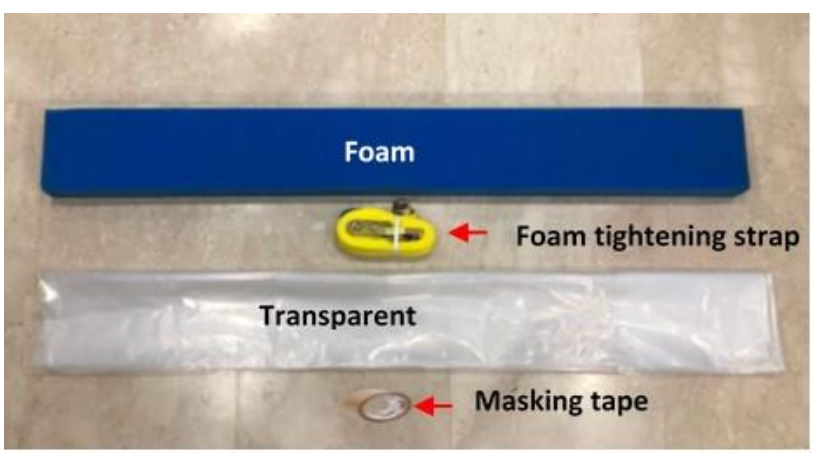

Figure 1. Material and apparatus used to assemble a gas entrapment cylinder/chamber on the RPW infested palm.
The treatments tested are presented in Table 1 . Entrapment of the phosphine gas around the infested site on the palm (usually the trunk) was ensured by securing a plastic wrap (4 meters long, 2.5 meters wide, 150 microns thick) on two foam pieces (toluene diisocyanate foam) encircling the palm above and below the infested site. The foam pieces were secured around the palm trunk initially by using an adhesive tape. Aluminium phosphide tablets were placed on the palm trunk around the infested site as per the treatment schedule mentioned in table 1. Subsequently, the plastic wrap was fastened to the foam at both the ends using masking tape, which was also used to seal both the longitudinal ends of the plastic wrap then the tightening strap was applied on the middle of the width of the two foams and tightened to the maximum limit using the mechanical tightening apparatus (Figure 2). Detailed treatment protocol is presented in table 2.

In treatment one, were 20 tablets were applied for 10 days in three splits of 10,5 and 5 at 1,3 \& 6 days, respectively application at 3 and 6 days was made by making a small slit on the wrap and sealing it with masking tape immediately upon inserting the tablets. In treatment five of this study, black plastic wrap was used to assess its impact on treatment duration.

Upon completion of the treatment duration, the plastic enclosure was removed and all treated palms were manually scrapped to remove the dead palm tissue and count the dead and live stages of the pest including larvae, pupae and adults. Data on pest mortality (\%) was subjected to statistical analysis (ANOVA where treatment means were separated using DUNCAN's Multiple Range Test). Phosphine gas levels (ppm) were also measured inside the gas entrapment cylinder on the palm and also outside the treated palm between 6 to 96 hours after treatment, using gas alert extreme a portable phosphine gas detector. Results of the study are presented and discussed below.

Table 1. Aluminium phosphide treatment imposed in RPW infested date palms

\begin{tabular}{lcccc}
\hline Treatment* & Number of Palms Treated & $\begin{array}{r}\text { Severity of } \\
\text { Infestation }\end{array}$ & $\begin{array}{c}\text { Distance of infestation } \\
\text { from ground }(\mathbf{c m})\end{array}$ & $\begin{array}{c}\text { Average age of treated palm } \\
\text { (years) }\end{array}$ \\
\hline T 1 & 100 & mild to severe & $40-90$ & 12 \\
T2 & 50 & mild to severe & $40-80$ & 12 \\
T3 & 50 & mild to severe & $40-80$ & 12 \\
T4 & 25 & mild to severe & $40-80$ & 12 \\
T5 & 50 & mild to severe & $10-60$ & 6 \\
T6 & 10 & mild to severe & $40-80$ & 12 \\
T7 & 10 & mild to severe & $40-80$ & 12 \\
\hline
\end{tabular}

* T1: 20 Tablets for 10 days applied in 3 Splits of $10,5 \& 5$ at 1,3 \& 6 Days, respectively [Transparent Plastic Wrap];

T2:15 Tablets for 10 days [Transparent Plastic Wrap];

T3:15 Tablets for 5 days [Transparent Plastic Wrap];

T4:10 Tablets for 10 days [Transparent Plastic Wrap];

T5:10 Tablets for 5 days [Black plastic wrap];

T6: 5 Tablets for 10days [Transparent Plastic Wrap];

T7: Control [No Treatment]

The above treatments were administered by staff using all protective gear including, hand gloves, nasal mask, eye goggles and safety shoes. 
Table 2. Protocol adopted to treat RPW infested date palms with aluminium phosphide

- Grass/weeds around the trunk of the palm were removed.

- The trunk of the palm was pruned very short to have maximum $5 \mathrm{~cm}$ frond base using a manual or automatic saw so as to remove any palm parts that may puncture the plastic.

Note: There is no need to clean the site of the infestation on the palm and remove the insect stages

- Two pieces of foam were carefully installed around the trunk of the palm so that the first was at a level of about 1.25 meters above entry site of the pest and the second at a level of about $1.25 \mathrm{~m}$ below entry site or at the level of the soil surface if the infestation site was low, and held the foam in place using the adhesive masking tape

- Aluminum phosphide tablets were placed around the trunk of the palm as per the treatment schedule presented above in table 1 near the entry site. (aluminum phosphide tablets usually start emitting toxic phosphine gas not less than 1 hour after exposure to air).

- The plastic sheet was placed neatly and quickly around the trunk of the palm so that it became two continuous layers of plastic around the trunk and was fixed in place using the adhesive masking tape.

- The tightening belt (strap) was placed on the plastic sheet on the middle of the width of the foam. The belt was then tightened so that the tightening strength reaches maximum to prevent phosphine gas from escaping.

- The tightening belt was also placed around the plastic sheet on the middle of bottom foam and the belt was tightened in the manner described above.

- Soil was placed above the bottom of plastic sheet and the soil was compacted

- On completion of the treatment duration the plastic sheet was removed quietly and carefully after removing the tightening belts from the top and bottom. The plastic sheet and belt can be used again several times provided it is not punctured

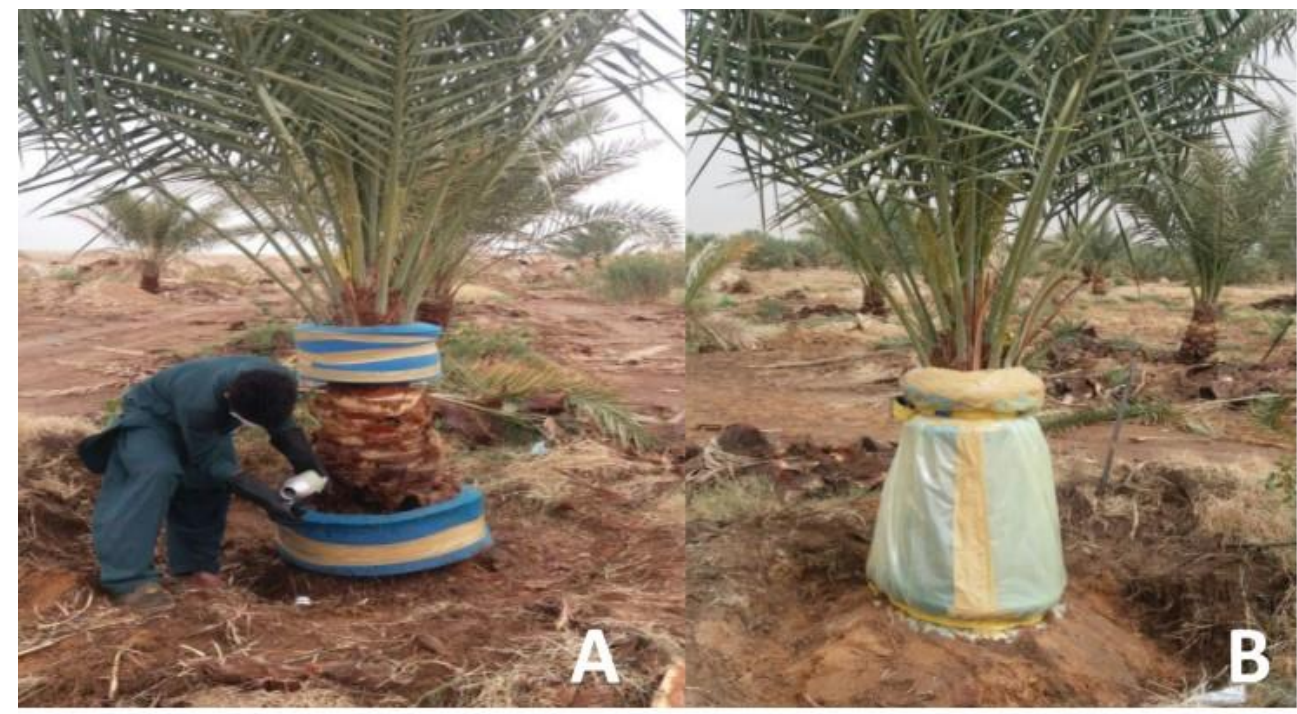

Figure 2. Foam (A) and plastic wrap (B) around the infested site on the palm ensuring complete entrapment of the phosphine gas

\section{Results and Discussion}

Results presented in table 3 indicate that the treatment means were highly significant ( $\mathrm{p}<0.0001)$ indicating that aluminium phosphide treatment of RPW infested palms is very effective in killing the hidden stages of the pest. However, what is required is to use the minimum dose for the shortest possible time to obtain $100 \%$ mortality. Although the first three treatments resulted in $100 \%$ mortality of all the three stages of the pest, either the dose or the duration were on the higher side. In an effort to reduce the number of tablets used (dose/palm) and duration to treat an infested palm,10 aluminium phosphide tablets for 10 days in transparent plastic wrap (T4) was not satisfactory as this resulted in several live stages of the pest (Table 3 and Figure 3). Also, in T6 (5 tablets for 10 days with transparent plastic wrap), live stages of the pest were detected. However, in T5, when 10 tablets were used for 5 days in black plastic wrap, $100 \%$ mortality of the larval, pupal and adult stages was obtained (table 3 and figure 3). It can be inferred that the black plastic wrap made the difference resulting in $100 \%$ mortality probably due to the longer half-life for phosphine gas in absence of exposure to light, allowing for higher phosphine gas level maintained for longer time 
Table 3. Mortality of different stages of RPW in date palm treated with aluminum phosphide

\begin{tabular}{lcccc}
\hline & \multicolumn{3}{c}{ \% Mortality ** } & \\
\cline { 2 - 4 } Treatment Name* & Adults & Larvae & Pupae & Number of insect stages dead/live \\
\hline T1 & $100.00 \mathrm{~A}$ & $100.00 \mathrm{~A}$ & $100.00 \mathrm{~A}$ & $5215 / 0$ \\
T2 & $100.00 \mathrm{~A}$ & $100.00 \mathrm{~A}$ & $100.00 \mathrm{~A}$ & $2007 / 0$ \\
T3 & $100.00 \mathrm{~A}$ & $100.00 \mathrm{~A}$ & $100.00 \mathrm{~A}$ & $2115 / 0$ \\
T4 & $94.00 \mathrm{~B}$ & $99.50 \mathrm{~A}$ & $96.00 \mathrm{~B}$ & $787 / 8$ \\
T5 & $100.00 \mathrm{~A}$ & $100.00 \mathrm{~A}$ & $100.00 \mathrm{~A}$ & $543 / 108$ \\
T6 & $76.55 \mathrm{C}$ & $67.02 \mathrm{~B}$ & $100.00 \mathrm{~A}$ & $0 / 100$ \\
T7 & $0.00 \mathrm{D}$ & $0.00 \mathrm{C}$ & $0.00 \mathrm{C}$ & \\
p-Value & $<0.0001$ & $<0.0001$ & $<0.0001$ & 6.00 \\
CV (\%) & 7.59 & 5.53 & \\
* & T1: 20 Tablets for 10 days applied in 3 Splits of 10,5 \& 5 at 1,3 \& 6 Days, respectively [Transparent Plastic Wrap] \\
T2:15 Tablets for 10 days [Transparent Plastic Wrap] & & \\
T3:15 Tablets for 5 days [Transparent Plastic Wrap] & & \\
T4:10 Tablets for 10 days [Transparent Plastic Wrap] & & \\
T5:10 Tablets for 5 days [Black plastic wrap] & \\
T6: 5 Tablets for 10days [Transparent Plastic Wrap] & \\
T7: Control [No Treatment] & & \\
** Means with at least one letter common are not statistically significant using DUNCAN's Multiple Range Test.
\end{tabular}

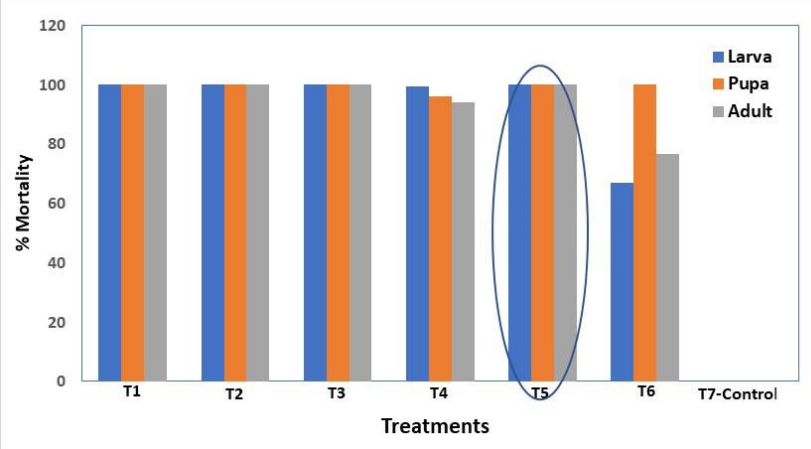

Figure 3. Mortality (\%) of RPW in infested palms treated with aluminum phosphide. T1: 20 Tablets for 10 days applied in 3 Splits of $10,5 \& 5$ at $1,3 \& 6$ days, respectively [transparent plastic wrap]; T2: 15 Tablets for 10 days [transparent plastic wrap]; T3: 15 Tablets for 5 days [transparent plastic wrap]; T4: 10 Tablets for 10 days [transparent plastic wrap]; T5: 10 Tablets for 5 days [black plastic wrap]; T6: 5 Tablets for 10days [transparent plastic wrap]; T7: Control [No Treatment]

Aluminum phosphide treatment of RPW infested coconut palms has been practiced since long and in date palms it is extensively practiced in UAE and Bahrain. 1-2 aluminum phosphide tablets have been used to cure RPW infested coconut and date palms (Lakshmanan et al., 1972; Subba Rao et al., 1973; Vidyasagar et al., 2000). However, there is no data on the duration of treatment and the precise protocol adopted to ensure that there is no escape of phosphine gas after treatment. Furthermore, inadequate sealing of the infested site on the palms results in escape of the phosphine gas. Our studies using a portable phosphine gas detector (GasAlert Extreme) revealed the detection of high levels of phosphine gas outside the plastic wrap for up to 36 hours after treatment in infested palms treated by the old method, this finding may contribute to the limited effectiveness of the old method. In palms treated by the method developed in this study no phosphine gas was detected outside the palm, while therapeutic levels of phosphine gas were detected inside the plastic wrap up to 7 days after treatment ensuring complete mortality of all pest stages.

Inappropriate treatments with aluminium phosphide could lead to enhanced levels of resistance. Studies carried out in Pakistan recorded high, Resistance Ratios (RRs) ranging from 63 to79 fold for phosphine (Wakil et al., 2018). This could lead to reduced effectiveness of the chemical. Studies carried out in Spain in $P$. canariensis suggest that a dose of $1.14 \mathrm{~g}$ aluminium phosphide/m 3 for 3 days is enough to kill all the stages of RPW in an infested palm tree, and is recommended as a quarantine protocol provided the dose is not phytotoxic to the treated palms (Llácer and Jacas 2010).

\section{Conclusion}

Treatment of RPW infested date palms in the susceptible age group of less than 15 years with 10 tablets of aluminum phosphide for 5 days in air tight black plastic wrap ensures $100 \%$ mortality of the larval, pupal and adult stages of the pest and is a cost effective, safe and easy method that can be adopted as a curative treatment in date palm. The technique is gaining popularity in Saudi Arabia. The method could form the basis of developing quarantine treatment of date palm offshoots. 


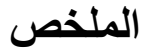

البلّاع، صالح وجو رومينو فاليرو. 2019. دراساتُّ للمعاملات العلاجية لمكافحة سوسة النخيل الحمراء

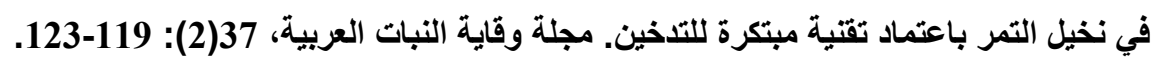

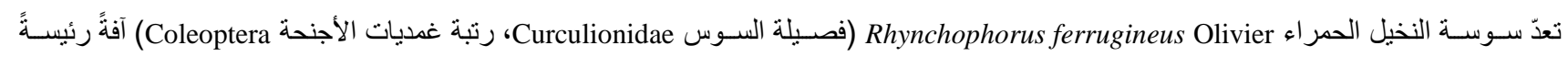
لأشـجار نخيل التّر .Phoenix dactylifera Lي منطقة الثـرق الأدنى وشـمال إفريقيا. تسـتجيب أثـجار نخيل التمر المصــابة بهذه الحشـرة للمعاملات الكيميائية

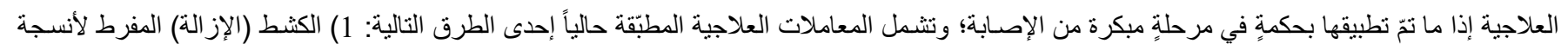

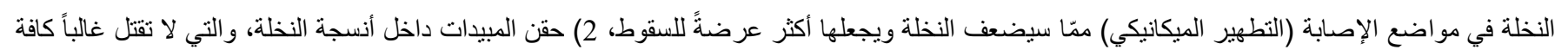

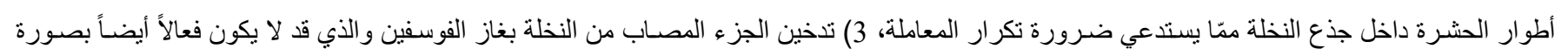

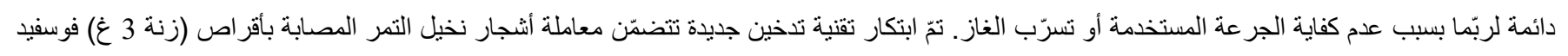
الألمنيوم مع إحكام السبطرة التامة على الغاز؛ وجرى اختبار هذه التقنية على 295 نخلةٍ بدرجاتٍ مختلفة من الإصـابة في منطقة القصيم، المملكة العربية السعودية،

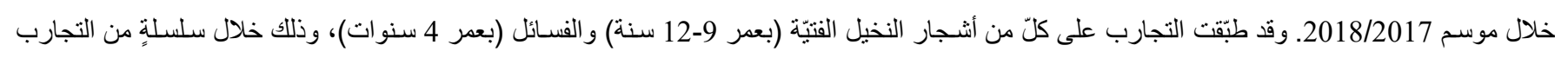

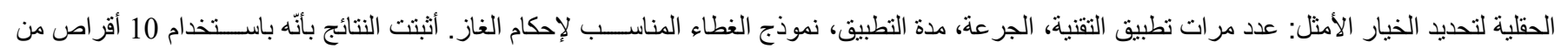

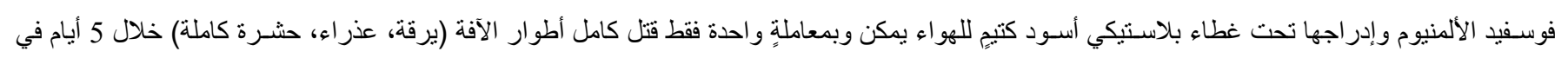

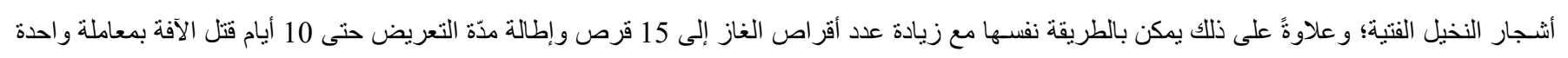
في حالة الفسائل. يمكن استخدام هذه التقنية لمعاملة النخيل المصاب سواءً في الحقل أو معاملة الفسائل عند تطبيق الحجر الزراعي؛ وتكتسب فئس هذه الطريقة في الوقت الحاضر شعبيةً في المملكة العربية السعودية. كلمات مفتاحية: المملكة العربية السعودية، فسائل، فوسفيد الألمنيوم، حجر زية زراعي، معاملة علاجية.

\section{References}

Abraham, V.A., M.A. Al-Shuaibi, J.R. Faleiro, R.A. Abozuhairah and P.S.P.V. Vidyasagar. 1998. An integrated management approach for red palm weevil, Rhynchophorus ferrugineus Oliv., a key pest of date palm in the Middle East. Sultan Qaboos University. Journal of Agricultural and Marine Sciences [JAMS]3: 77-83. https://doi.org/10.24200/jams.vol3iss1pp77-83

Faleiro, J.R. 2006. A review of the issues and management of the red palm weevil Rhynchophorus ferrugineus (Coleoptera: Rhynchophoridae) in coconut and date palm during the last one hundred years. Journal of Tropical Insect Science, 26: 135-150. https://doi.org/10.1079/IJT2006113

Faleiro, J.R., M. Ferry, T. Yaseen and S. Al-Dobai. 2018. Overview of the gaps, challenges and prospects of red palm weevil management. Presented at the International Scientific Meeting on 'Innovative and sustainable approaches to control the Red Palm Weevil', CIHEAM Bari, 23-25 October 2018, Organized by FAO and CIHEAM Bari, Italy.

Fiaboe, K.K.M., A.T. Peterson, M.T.K. Kairo and A.L. Roda. 2012. Predicting the potential worldwide distribution of the red palm weevil Rhynchophorus ferrugineus (Olivier) (Coleoptera: Curculionidae) using ecological niche modeling. Florida Entomologist, 95: 659-673. https://doi.org/10.1653/024.095.0317

Giblin-Davis, R.M., J.R Faleiro, J.A. Jacas, J.E. Peña and P.S.P.V. Vidyasagar. 2013. Coleoptera: Biology and management of the red palm weevil, Rhynchophorus ferrugineus. Pages 1-34. In: Potential Invasive Pests of Agricultural Crop Species. J.E. Peña (ed.), CABI Wallingford, UK.
Lakshmanan, P.L., P.V. Subba Rao and T.R. Subramaniam. 1972. A note on the control of the coconut red palm weevil, Rhynchophorus ferrugineus with certain new chemicals. Madras Agricultural Journal, 59: 638-639.

Llácer, E. and J.A. Jacas. 2010. Efficacy of phosphine as a fumigant against Rhynchophorus ferrugineus (Coleoptera: Curculionidae) in palms. Spanish Journal of Agricultural Research, 8: 775-779. https://doi.org/10.5424/sjar/2010083-1278

Milosavljević, I., H.A.F. El-Shafie, J.R. Faleiro, C.D. Hoddle, M. Lewis and M.S. Hoddle. 2018. Palmageddon: the wasting of ornamental palms by invasive palm weevils, Rhynchophorus spp. Journal of Pest Science, 92: 143-156. https://doi.org/10.1007/s10340-018-1044-3

Subba Rao, P.V., T.R. Subramaniam and E.V. Abraham. 1973. Control of red palm weevil on coconut. Journal of Plantation Crops, 1: 26-27

Wakil, W., M. Yasin, M.A. Qayyum, M.U. Ghazanfar, A.M. AlSadi, G.O. Bedford and Y.J. Kwon. 2018. Resistance to commonly used insecticides and phosphine fumigant in red palm weevil, Rhynchophorus ferrugineus (Olivier) in Pakistan. PLoS ONE 13: e0192628 https://doi.org/10.1371/journal.pone.0192628

Vidyasagar, P.S.P.V., A.A. Al- Saihati, O.E. Al-Mohanna, A.I. Subbei and A.M. Abdul Mohsin. 2000. Management of red palm weevil Rhynchophorus ferrugineus Olivier. A serious pest of date palm in Al-Qatif, Kingdom of Saudi Arabia. Journal of Plantation Crops, 28: 35-43. 